\title{
Household Waste Quantities and Problem of Management in Port Harcourt
}

\author{
Umunnakwe Johnbosco Emeka ${ }^{1,}$, , Njoku Richard Ebere², Aharanwa Bibiana Chimezie ${ }^{3}$, \\ Umunnakwe Bernadine Akuoma ${ }^{4}$
}

${ }^{1}$ Department of Environmental Management, Federal University of Technology, Owerri, Nigeria

${ }^{2}$ Department of Surveying and Geoinformatics, Federal University of Technology, Owerri, Nigeria

${ }^{3}$ Department of Polymer and Textile Engineering, Federal University of Technology, Owerri, Nigeria

${ }^{4}$ Department of Science Education, Ignatius Ajuru University of Education, Port Harcourt, Nigeria

Email address:

jnboscokwe@yahoo.com (U. J. Emeka)

${ }^{*}$ Corresponding author

\section{To cite this article:}

Umunnakwe Johnbosco Emeka, Njoku Richard Ebere, Aharanwa Bibiana Chimezie, Umunnakwe Bernadine Akuoma. Household Waste Quantities and Problem of Management in Port Harcourt. American Journal of Environmental and Resource Economics.

Vol. 6, No. 1, 2021, pp. 1-10. doi: 10.11648/j.ajere.20210601.11

Received: December 11, 2020; Accepted: February 3, 2021; Published: February 27, 2021

\begin{abstract}
The research evaluated the progressive increase and in-depth analysis of the quantity and the percentage composition of household waste generated and the problems of management in Port Harcourt metropolis, Rivers state of Nigeria. The accumulation of large quantities of household waste in the city and the unsustainable management is worrisome because of the strategic position of Port Harcourt as the hub of multinational companies especially in the oil and gas sector in Nigeria and its status as the garden city. This has led to flooding as it blocks the drains, poor aesthetics, increased surface temperature as a result of emissions of greenhouse gases and a factor to public health risk. The state government in 2001 set up a technical committee on urban solid waste management for Port Harcourt metropolis to prepare a blue print on solid waste management between 2001 and 2031 and quantitative determination of household wastes generated. This present research work focused on data gathering of volume of household wastes generated and their compositions ten years after field work data of the committee. The results of the research indicated that a total of 647,066 metric tonnes of household waste was generated by an estimated population of 1,911,000 inhabitants in Port Harcourt and the percentage composition is as follows, food waste $44.5 \%$, sachet bags $17.3 \%$, paper $15.7 \%$, plastics $7.5 \%$, garden waste $4.4 \%$, Textile $2.2 \%$, Electricals, $1.8 \%$, glass $1.2 \%$, Napies and others $1.3 \%$. There was an appreciable increase from the quantity generated in 2001 which was 342,352 tonnes by an estimated population of $1,148,000$. The progressive rise in the quantity of household waste generated without any appropriate management strategy in place remains an obstacle to sustainable waste management in Port Harcourt metropolis. It is recommended that key elements of waste management and modern waste management strategies of prevention and reduction, reuse, recycling and recovery operations be adopted by people, government, service providers in Port Harcourt metropolis.
\end{abstract}

Keywords: Household, Port Harcourt, Wastes, Management, Quantity, Generation, Percentage

\section{Introduction}

Waste can be defined as any substance for which the user has derived benefits from, and needs to be disposed; though the material may still be very useful for other purposes [1]. Generally, wastes of all forms are primarily the creation of normal human living. In the same vein, any substance or article which requires to be disposed of as broken, worn out or otherwise spent constitutes a waste [2]. Waste generation and composition is greatly influenced by population, income, economic growth, season, climate and social behaviour [3].

In Port Harcourt metropolis (comprising Port Harcourt city and Obio Akpor Local Government Areas), refuse is generated from domestic, commercial and industrial sources, 
but household waste is predominant [4]. Indiscriminate dumping of household waste such as polythene, plastics, food waste, sachet water bags, glass etc in and around the city is very common [5]. Currently, world cities generate about 1.3 billion tonnes of solid waste per year [6]. This volume is expected to increase to 2.2 billion tonnes by 2025 . Waste generation rates will more than double over the next twenty years in lower income countries. Globally, solid waste management costs will increase from today’s annual \$205.4 billion to about $\$ 375.5$ billion in 2025 especially in low income countries [7]. This report estimates that the 2.9 billion urban residents in 2002 who generated about $0.64 \mathrm{~kg}$ of household waste per person ( 0.68 billion tonnes per year) have increased to about 3 billion residents in 2012 generating
$1.2 \mathrm{~kg}$ per person per day (1.3 billion tonnes per year). By 2025 this will likely increase to 4.3 billion urban residents generating about $1.42 \mathrm{~kg} /$ capita/day of municipal solid waste i.e 2.2 billion tonnes per year [6]. Projections for urban municipal solid waste generation in 2025 were made by factoring expected growth in population and GDP and estimated per capita waste generation. The World Bank report of 2011 stated that Nigeria with a population of 162 , 470, 737 with a GDP of US\$ 235.9 billion, faces a complex challenge of solid waste management in the Country with increase in population, urbanization and industrialization including globalization [8].

There are varied data on waste generation and composition due in major Nigerian cities as shown below:

Table 1. Data on waste generation and composition on some Nigerian cities.

\begin{tabular}{|c|c|c|c|c|}
\hline City & Population & Tonnage/month & Density $\mathrm{kg} / \mathrm{m}^{3}$ & Kg/Capita/Day \\
\hline Lagos & $8,029,200$ & 255,556 & 294 & 0.63 \\
\hline Kano & $3,248,700$ & 156,676 & 290 & 0.56 \\
\hline Ibadan & 307,840 & 135,391 & 330 & 0.51 \\
\hline Kaduna & $1,458,900$ & 114,433 & 320 & 0.58 \\
\hline Port Harcourt & $1,053,900$ & 117,825 & 300 & 0.60 \\
\hline Makurdi & 249,000 & 24,242 & 340 & 0.48 \\
\hline Onitsha & 509,500 & 84,137 & 310 & 0.53 \\
\hline Abuja & 159,900 & 14,785 & 280 & 0.66 \\
\hline
\end{tabular}

Source: TC Ogwueleke, 2009

During the period of study, the rate of waste generation in Lagos (with estimated population of over 10 million in 2012) was 9, 000 tonnes/day [9] while in Kano State, the rate was 3, 849 tonnes/day [10]. Port Harcourt metropolis with a population of I, 053,900 in 2009 was third with generation rate of $0.60 \mathrm{~kg} / \mathrm{capita} /$ day. Generally, the average rate of generation for Nigerian cities is estimated as $0.5 \mathrm{~kg} / \mathrm{capital} /$ day. Biodegradable waste accounted for over $50 \%$ of waste generated with other components estimated at different composition in different States. A recent study estimated the following household waste composition for Polythene/cellophane $=19 \%, \quad$ Paper $=12.7 \%, \quad$ Metal $=10 \%$, Glass $=8.7 \%$, Plastic $\mathrm{s}=11.3 \%$, Fines (ash, dust and sand) $=12 \%$ Miscellaneous $=9 \%[10]$.

Waste management is the processes involved in dealing with the wastes of humans and organisms, including minimization, handling, processing, storage, recycling, transport and final disposal [11]. The problem of solid waste management in Port Harcourt has assumed a worrisome dimension, considering the progressive increase in quantity generated [12]. The ineffective management of household wastes has led to flooding, increase in atmospheric surface temperature and foul odours. The accumulation of refuse on the entire place has created fertile breeding ground for rodents, flies, which are disease vectors and also the aesthetics of the metropolis, which poses public health risk [13].

\subsection{Overview of Household Waste Problems, Volume and Management in Port Harcourt, Rivers State}

Waste problems in Port Harcourt became manifest during the oil boom of the 1970's when the economy of Nigeria witnessed an unprecedented growth occasioned by lifestyles, high level of income, industrial activities and constructions [14]. Consequently, in Port Harcourt as in other parts of Nigeria cities household waste is usually disposed of illegally beside houses, in gutters, pits and empty spaces [15]. It was during this period that a number of policy statements were issued and draft legislation proposed but not promulgated into Law. However, with the advent of modernization and increasing human population, the socioeconomic activities in the metropolis became more complex, so did the kind of waste generated [16]. To contain the problems of waste management in Nigeria; the Colonial administration introduced bye-Laws on waste management, enforced by Sanitary Inspectors or Environmental Health Officers as it is currently known and called and this process and strategies worked very well as at then. However, the volume and complexity of the waste generated especially in the urban areas such as Port Harcourt needed a more demanding system of legislation, for which the Environmental Sanitation Edict of 1984/86 was set up to manage our environment [17]. This threw light and the need; even before the National Policy of Environment, NPE of 1989 was made. The National Waste Management Policy is embodied in the National Policy of Environment (NPE) formulated in 1989 and revised in 1992 [18]. This Policy was developed to manage waste in the Country with objectives to:

a) Study the most reliable treatment systems that are appropriate for domestic and industrial waste.

b) Design and specify appropriate waste disposal and treatment systems that will take into account the 
geographical and environmental setting, encourage recycling and guarantee the safety of surface and underground water systems.

c) Set up and enforce standards for sanitary facilities in both urban and rural areas etc.

Between 1984 - 1986 Port Harcourt metropolis witnessed a tremendous improvement in management of household waste and other municipal solid waste as a result of Environmental Health Officers that were engaged in routine house to house inspection and enforcement of the Sanitary Laws [19]. The establishment of Environmental Sanitation Authority backed up by edict of $1984-86$, authorizing them to clean and dispose all solid waste in Port Harcourt and its environs with the assistance of military enforcement was an additional step in the right direction [20]. Also with the engagement of foreign partners; Sulo Waste Management Company from Germany, Port Harcourt became the first city to regain Garden City Status in Nigeria in 1985. Waste bins were strategically located to every nooks and crannies, street and road in Port Harcourt with modern refuse disposal van called compactors and roll off trucks, which made the city became very clean and attracted many investors. However contemporary political developments have disrupted the foregoing and everything changed for the worse.

\subsection{Technical Committee on Urban Solid Waste Management for Port Harcourt and Its Environs Report (2001)}

The main objectives and scope of work of the solid waste management plan are:

a. To prepare a feasibility study with project design, regarding solid waste management in Port Harcourt;

b. To prepare and formally present to the Rivers State Government a blue print on solid waste management;

c. Work in conjunction with AGIP to outline an overall management solution for sustainable solid waste management system for the State;

d. Design an appropriate data collection and analysis system, and produce a feasibility report;

e. Design an appropriate solid waste minimization strategy for the State as a whole, based on the associated problems identified with existing solid waste solid waste management systems.

In the preliminary data gathering effort, the survey employed both the primary and secondary data sources [21]. The field research strategy includes:

i. Demarcation of Port Harcourt metropolis into 12 zones

ii. Demarcation of the boundaries of these zones on the map to aid in data analysis.

iii. Face-to-face interview of households and industrial establishments, and

iv. Direct observations and measurements of solid waste profile in industrial and residential areas.

Results indicate the absence of any waste management strategy in place. Actually the survey revealed that wastes of all types and compositions find their way to the public dumps without sorting or any form of treatment. But using population studies and the exponential growth model, the survey estimated waste load to be generated in the study area for the years 2001 to 2031 . The per capita waste generation was found to be between 0.39 and 0.41 metric tons per year.

\section{Methods}

The methods involved techniques used for the collection of household wastes and their measurements at various study areas as demarcated in the research design.

\subsection{Collection and Measurement of Household Waste Quantity in Port Harcourt}

Measurements of household wastes generated weekly in kilogrammes in sampled households during the study period were carried out by weighing them from bin liners where they are been collected. Bin liners were distributed to various households to sort their wastes generated daily during the field survey, which were weighed daily by our field workers. A total number of four thousand nine hundred and thirty one (4931) street buildings and sixteen thousand and sixteen $(16,016)$ households were sampled. This was aimed at determining the percentage composition of different sources of household waste. The daily quantities of household wastes in tones disposed in government approved dumpsites with 5\% error [11] were recorded to determine the yearly generation tonnage with the assistance of a waste collection company Firimabo Nigeria Limited, Port Harcourt, Rivers State. Bin liners were distributed to the various households sampled and the wastes generated disposed directly into them. The waste generated weekly by each household was being determined by direct measurement with weighing scale (measuring up to $50 \mathrm{~kg}$ ). Wastes were sorted into the various sources of generation: Food, Tins, Can, Plastics, Sachets, Paper (including Cardboard), Electrical Items, Green Waste and Others (nappies, wood and glass); and the weight of each type determined from the different bin liners they were collected [22-24].

\subsection{Sampling Zones in the Study Area}

Table 2. Showing Different Sampled Zones of the Study Area.

\begin{tabular}{ll}
\hline Zones & Areas of coverage \\
\hline 1 & Agip (Mgbuosimili) \\
2 & Woji \\
3 & DGRO (D/line, GRA, Rumuola, Ogbunabali) \\
4 & RRR (Rukpuokwu, Rumuodumanya, Rumuokoro) \\
5 & Diobu \\
6 & Outskirt (Eagle Island, Iwofe, Nkpor) \\
7 & Oil Mill (Elelenwo, Eleme Road) \\
8 & Borokiri \\
9 & State Secretariat (Amadi - Flat, Government House) \\
10 & Old Port Harcourt Township) \\
\hline
\end{tabular}

\subsection{Ways of Household Waste Collection}

Waste collections from households were collected from point of production (residential) in several ways:

1. House-to-House: Our field workers during the research visited each individual household to collect garbage in 
the closed bin liners to avoid disturbance by vermin such as dogs and rats, or it becoming water-logged,

2. Community Bins: Users brought their garbage to community bins that are placed at fixed stations in a neighborhood or locality according to a set schedule.

3. Curbside Pick-Up: Users kept their garbage directly outside their homes according to a garbage pick-up schedule set with the field work team
4. Self-Delivered: Generators delivered the waste directly to disposal sites or transfer stations. This arrangement were often worked out with the field survey team.

Statistical tools such as mean and standard deviation were used to analyse the data obtained to ascertain how representative the samples are and how close the data obtained are. Descriptive statistical tools like bar charts and line graph were employed to present the data obtained.

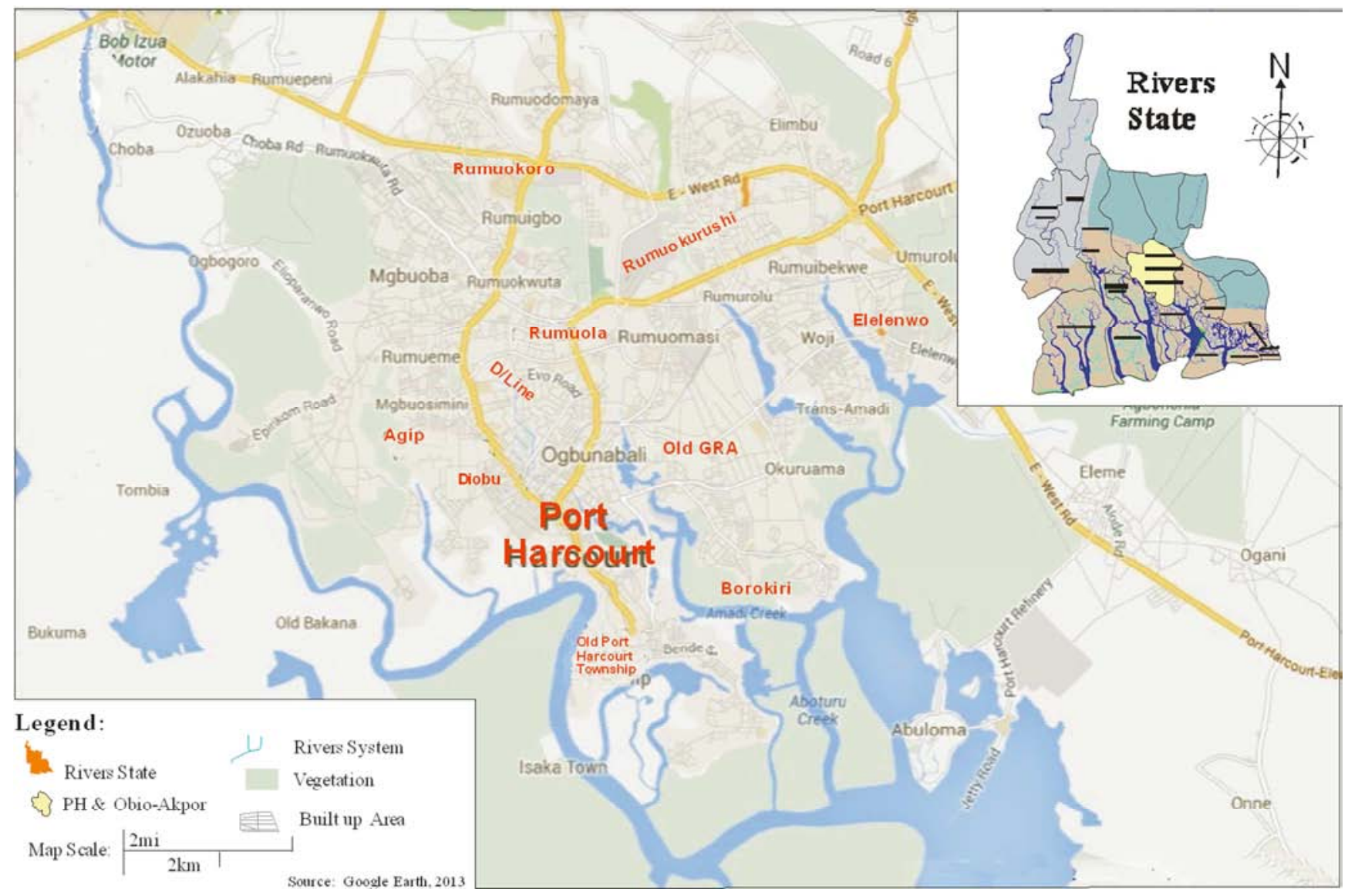

Figure 1. Map of Rivers State showing Studied Areas (in red prints) in Port Harcourt and Obio-Akpor L.G.A.

\section{Results}

Household Wastes Volumes in Port Harcourt Metropolis from May 2011 to April 2012.

Table 3 showed the household waste tonnages generated in Port Harcourt metropolis from May 2011 to April 2012. The monthly tonnages from different sources of generation were shown in Figures 2 to 11; while the cumulative waste generated in the households during the study period was shown in Figure 12.

Paper: The total quantity of paper generated in the households from May 2011 to April 2012 was 96,427 tones, with monthly tonnages shown in Figure 2.

Food: The total quantity of food waste generated in the households from May 2011 to April 2012 was 269,870 tones, with monthly tonnages shown in Figure 3.

Plastic: The total quantity of plastic waste generated in the households from May 2011 to April 2012 was 43,019 tones, with monthly tonnages shown in Figure 4.
Glass: The total quantity of glass waste generated in the households from May 2011 to April 2012 was 7,278 tones, with monthly tonnages shown in Figure 5.

Electricals: The total quantity of electrical waste generated in the households from May 2011 to April 2012 was 10,920 tones, with monthly tonnages shown in Figure 6.

Can: The total quantity of can waste generated in the households from May 2011 to April 2012 was 26,084 tones, with monthly tonnages shown in Figure 7.

Garden: The total quantity of garden waste generated in the households from May 2011 to April 2012 was 26,685 tones, with monthly tonnages shown in Figure 8.

Textile: The total quantity of textile waste generated in the households from May 2011 to April 2012 was 13,343 tones, with monthly tonnages shown in Figure 9.

Others (nappies, wood, tin): The total quantity of other waste generated in the households from May 2011 to April 2012 was 7,893 tones, with monthly tonnages shown in Figure 10. 
Sachet bag: The total quantity of sachet bag generated in the households from May 2011 to April 2012 was 104,916 tones, with monthly tonnages shown in Figure 11.
Cumulative waste generated in the households from May 2011 to April 2012 was 647,066 tones, with different sources was shown in Figure 12.

Table 3. Household Wastes Tonnages Generated in Port Harcourt Metropolis from May 2011 to April 2012.

\begin{tabular}{|c|c|c|c|c|c|c|c|c|c|c|c|c|c|}
\hline \multirow{2}{*}{ Month / Year } & \multicolumn{8}{|l|}{2011} & \multicolumn{4}{|l|}{2012} & \multirow{2}{*}{ Total } \\
\hline & May & June & July & Aug. & Sept. & Oct. & Nov. & Dec. & Jan. & Feb. & Mar & Apr. & \\
\hline \multicolumn{14}{|l|}{ Waste Category } \\
\hline Paper & 10,029 & 8,403 & 6,821 & 8,459 & 4,198 & 6,425 & 8,118 & 8,424 & 7,394 & 8,335 & 10,210 & 9,611 & 96,427 \\
\hline Food & 28,066 & 23,516 & 19,091 & 23,672 & 11,750 & 17,982 & 22,721 & 23,575 & 20,694 & 23,326 & 28,577 & 26,900 & 269,870 \\
\hline Plastic & 4,478 & 3,752 & 3,046 & 3,777 & 1,875 & 2,869 & 3,625 & 3,761 & 3,302 & 3,722 & 4,560 & 4,252 & 43,019 \\
\hline Glass & 757 & 634 & 515 & 638 & 317 & 485 & 613 & 636 & 558 & 629 & 771 & 725 & 7,278 \\
\hline Electrical & 1,135 & 951 & 772 & 958 & 475 & 727 & 920 & 957 & 837 & 944 & 1,156 & 1,088 & 10,920 \\
\hline Can & 2,720 & 2,272 & 1,845 & 2,287 & 1,135 & 1,738 & 2,195 & 2,278 & 2,000 & 2,254 & 2,761 & 2,599 & 26,084 \\
\hline Garden & 2,775 & 2,325 & 1,888 & 2,341 & 1,162 & 1,778 & 2,247 & 2,331 & 2,046 & 2,306 & 2,826 & 2,660 & 26,685 \\
\hline Sachet Bags & 10,911 & 9,142 & 7,422 & 9,203 & 4,568 & 6,991 & 8,833 & 9,165 & 8,045 & 9,068 & 11,110 & 10,458 & 104,916 \\
\hline Textile & 1,388 & 1,163 & 944 & 1,170 & 581 & 889 & 1,123 & 1,166 & 1,023 & 1,153 & 1,413 & 1,330 & 13,343 \\
\hline $\begin{array}{l}\text { Others (eg. } \\
\text { Nappies etc.) }\end{array}$ & 819 & 687 & 558 & 696 & 343 & 526 & 668 & 689 & 605 & 681 & 835 & 786 & 7,893 \\
\hline
\end{tabular}

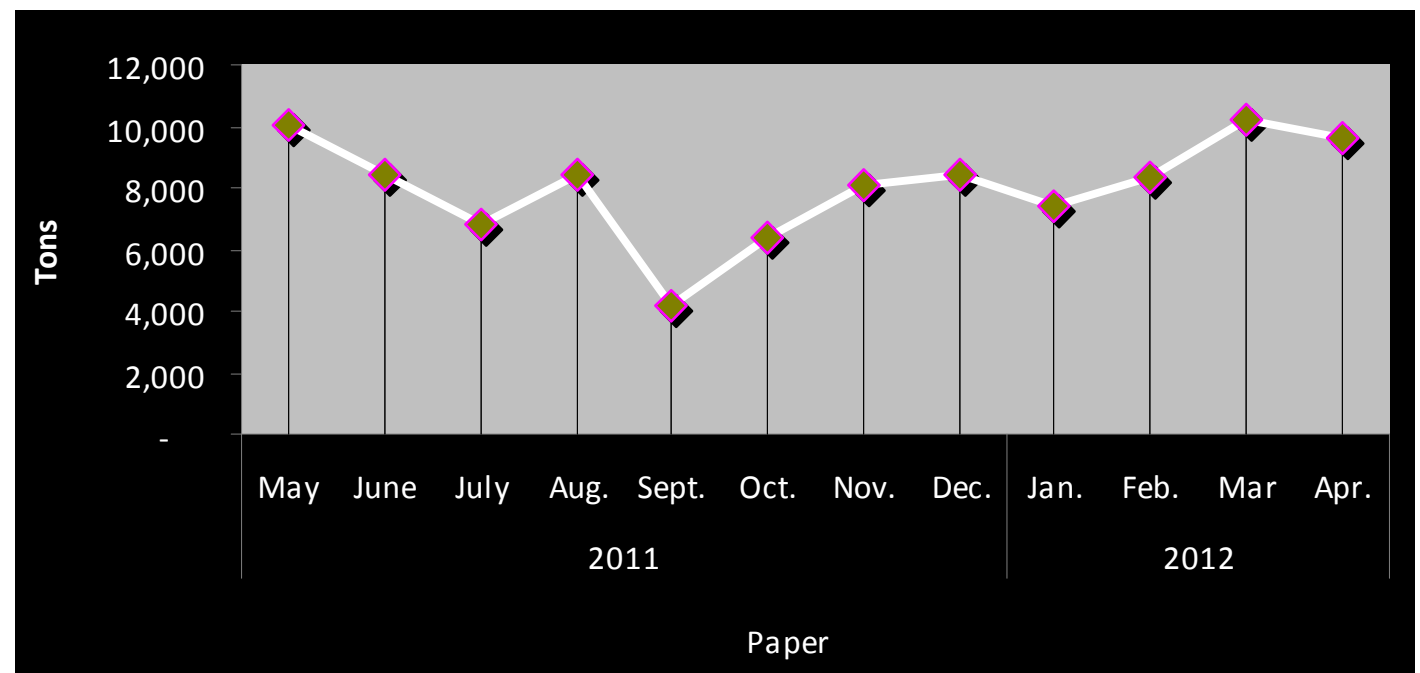

Figure 2. Monthly tonnages of total Paper wastes generated in the households of Port Harcourt metropolis during the study period.

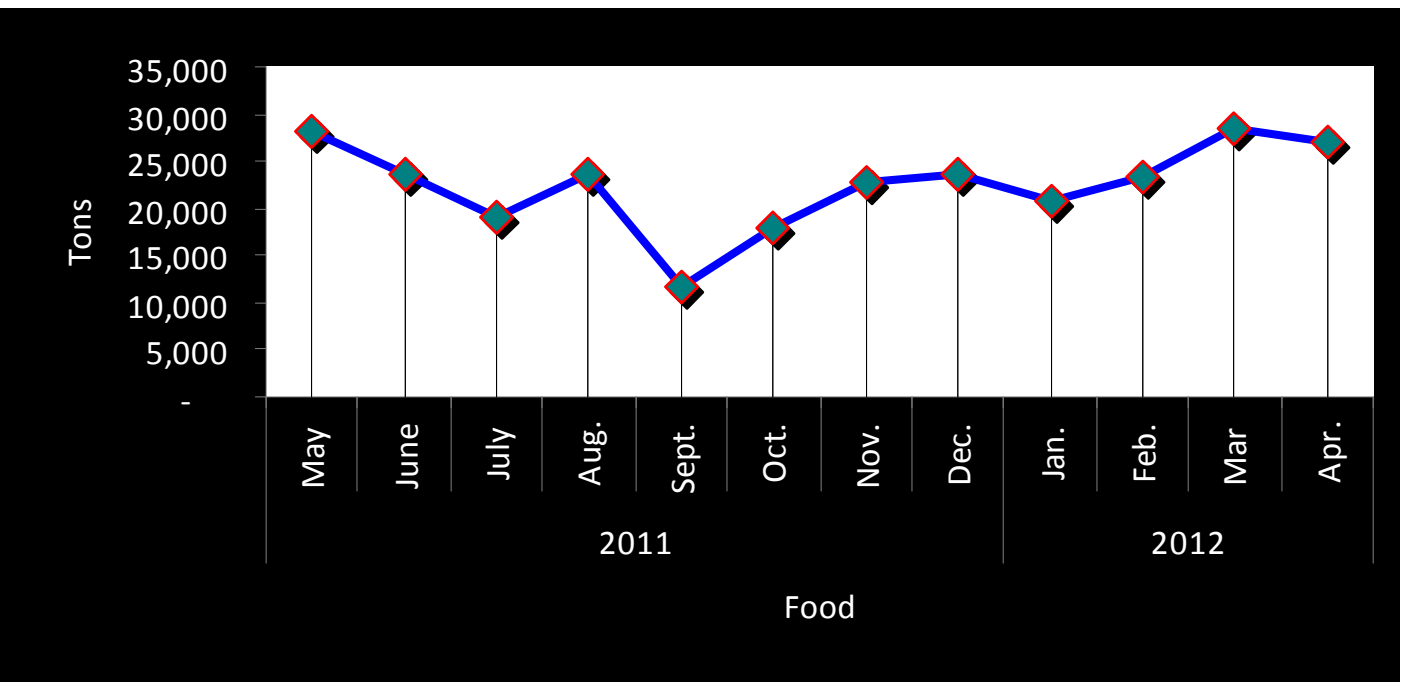

Figure 3. Monthly tonnages of total Food wastes generated in the households of Port Harcourt metropolis during the study period. 


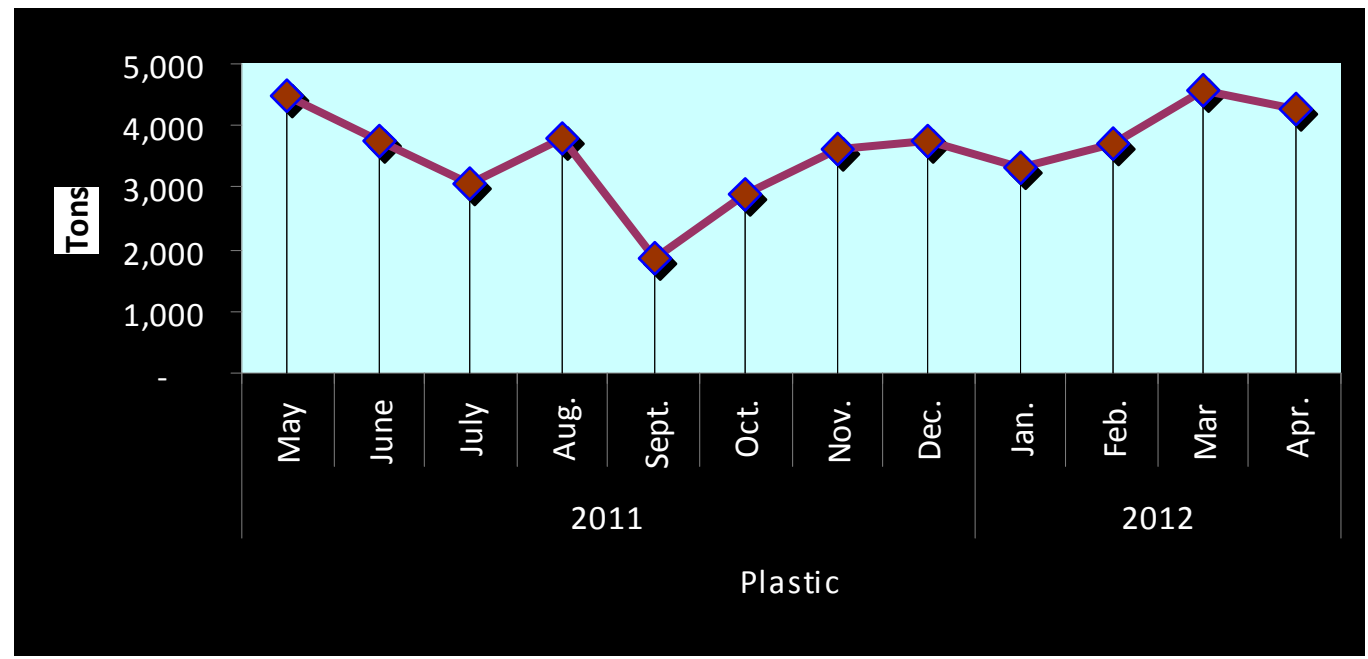

Figure 4. Monthly tonnages of total Plastic wastes generated in the households of Port Harcourt metropolis during the study period.

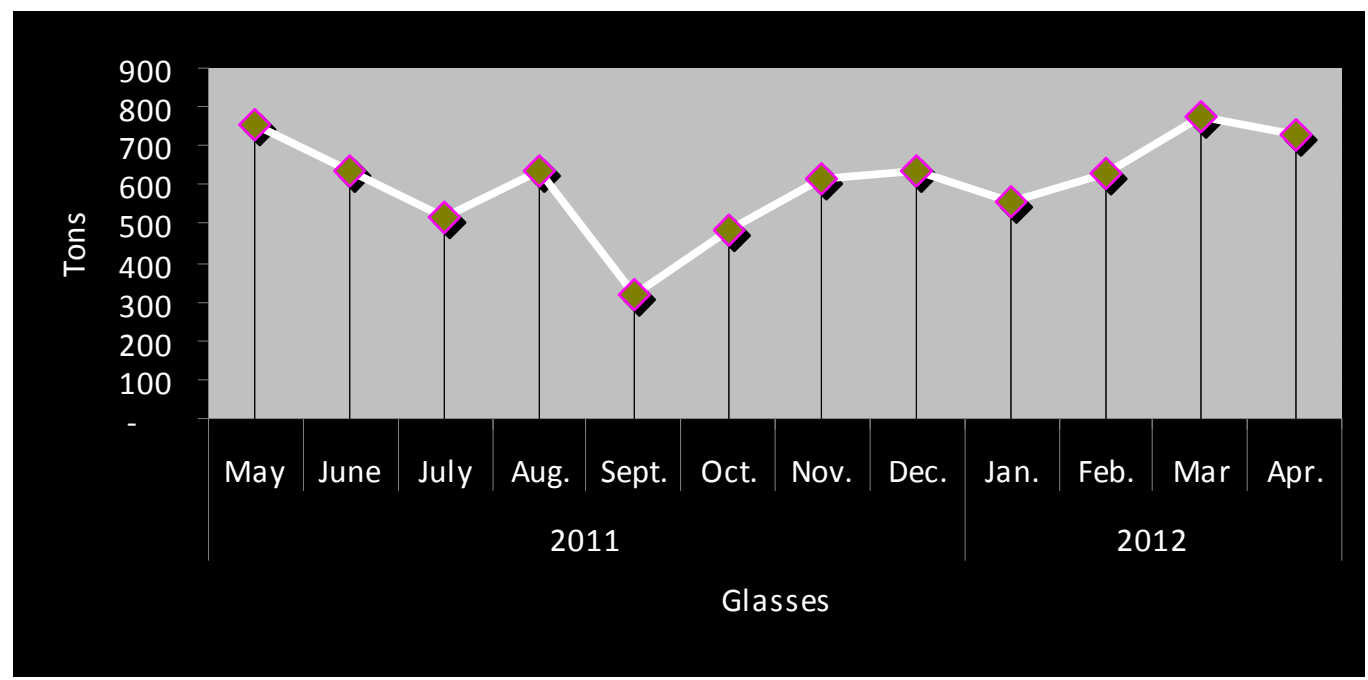

Figure 5. Monthly tonnages of total Glass wastes generated in the households of Port Harcourt metropolis during the study period.

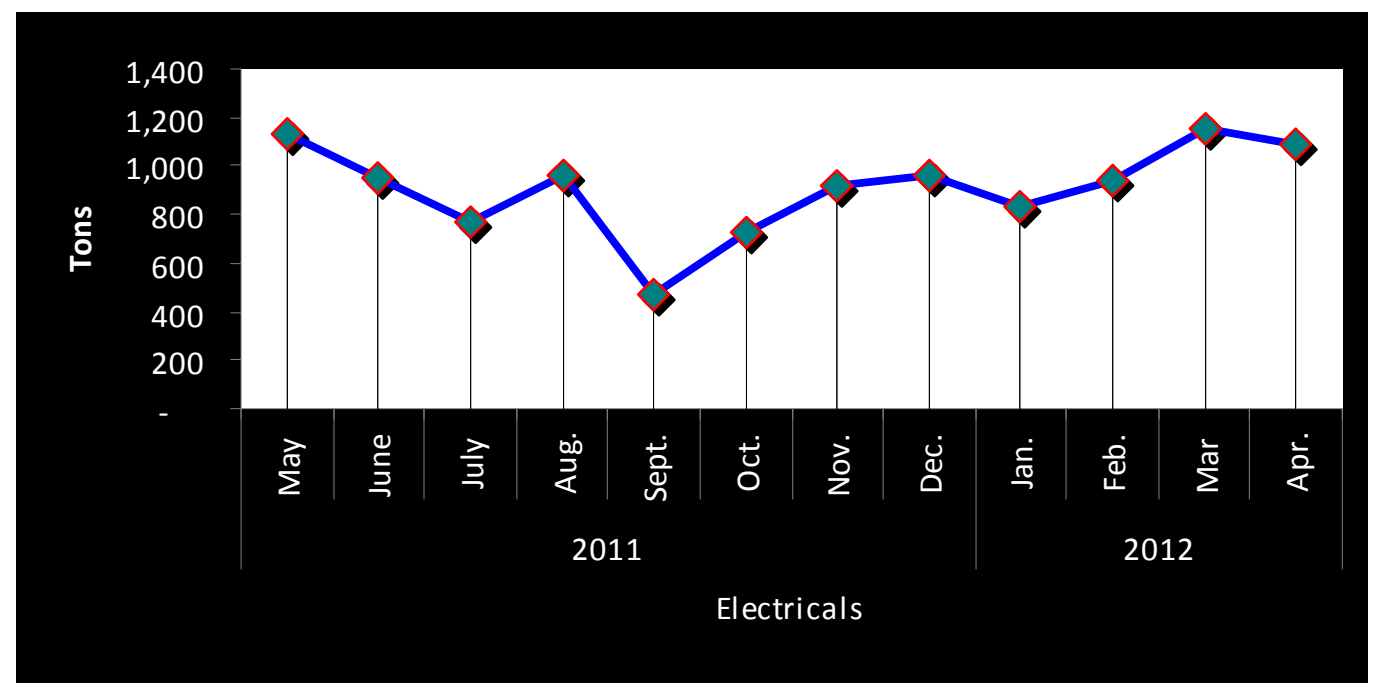

Figure 6. Monthly tonnages of total Electricals wastes generated in the households of Port Harcourt metropolis during the study period. 


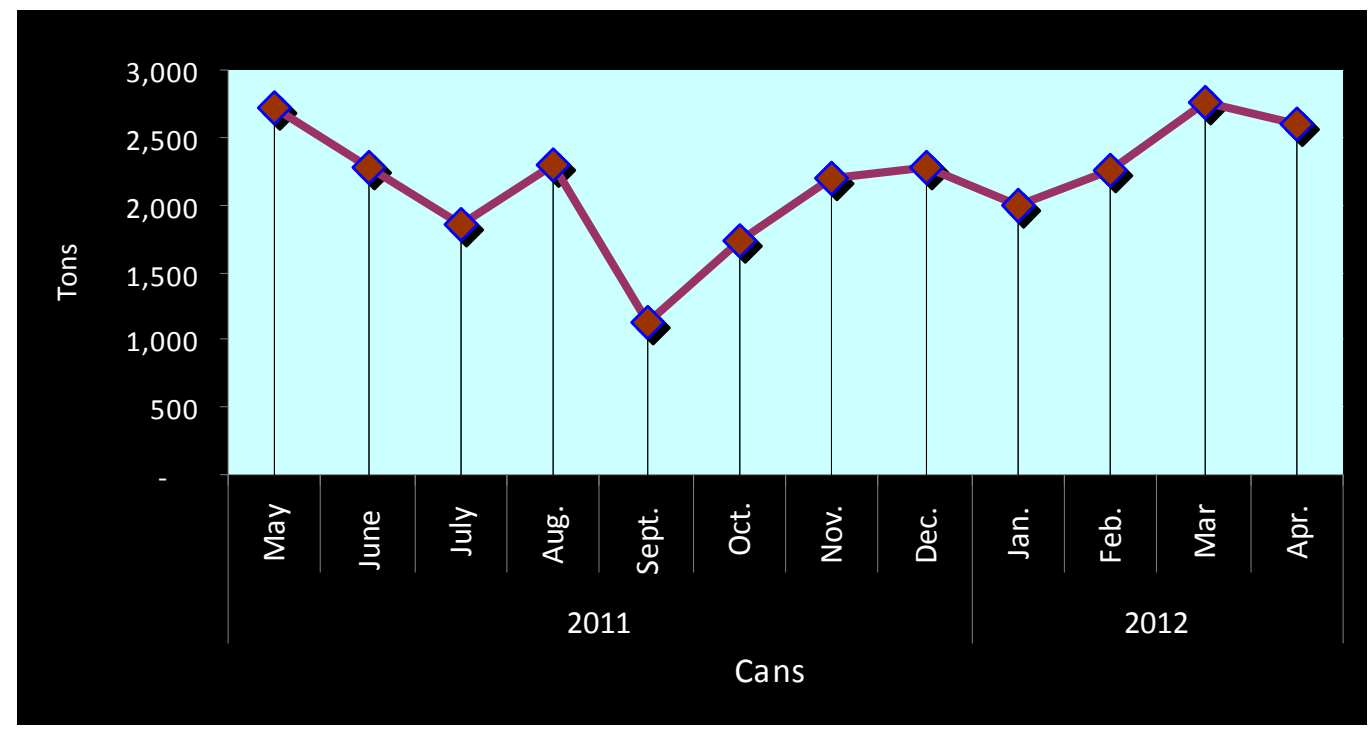

Figure 7. Monthly tonnages of total Can wastes generated in the households of Port Harcourt metropolis during the study period.

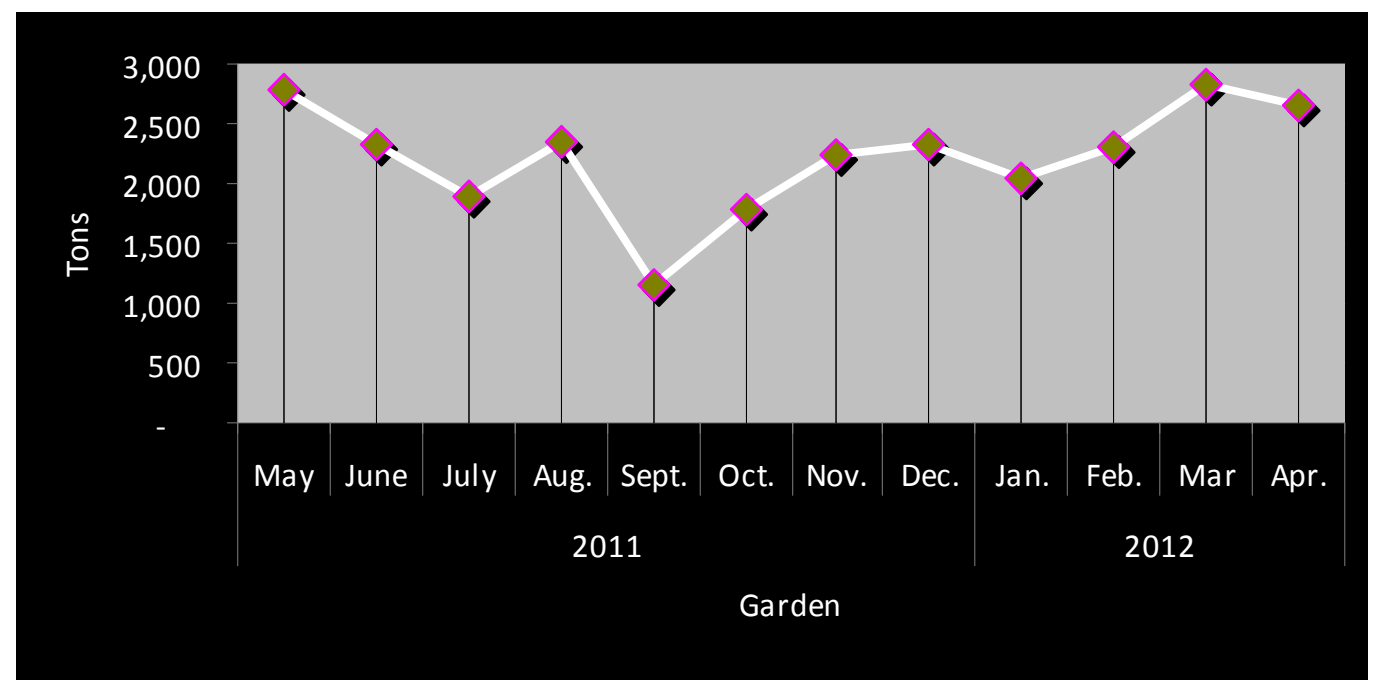

Figure 8. Monthly tonnages of total Garden wastes generated in the households of Port Harcourt metropolis during the study period.

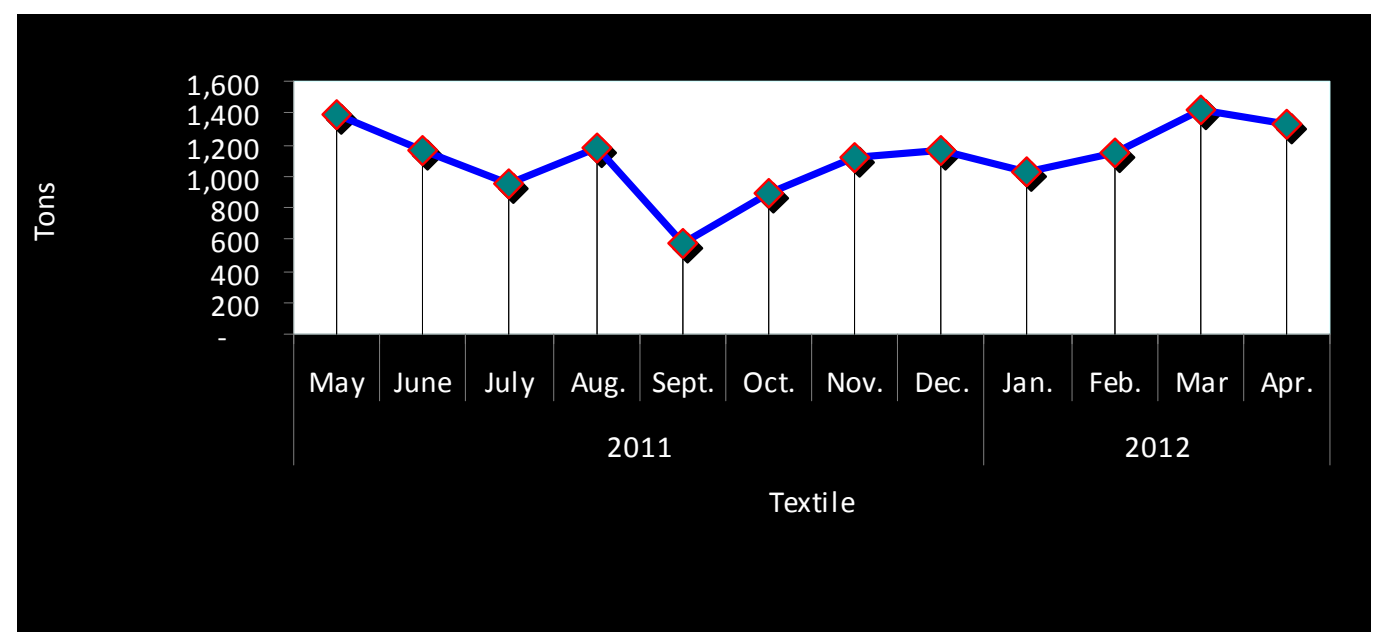

Figure 9. Monthly tonnages of total Textile wastes generated in the households of Port Harcourt metropolis during the study period. 


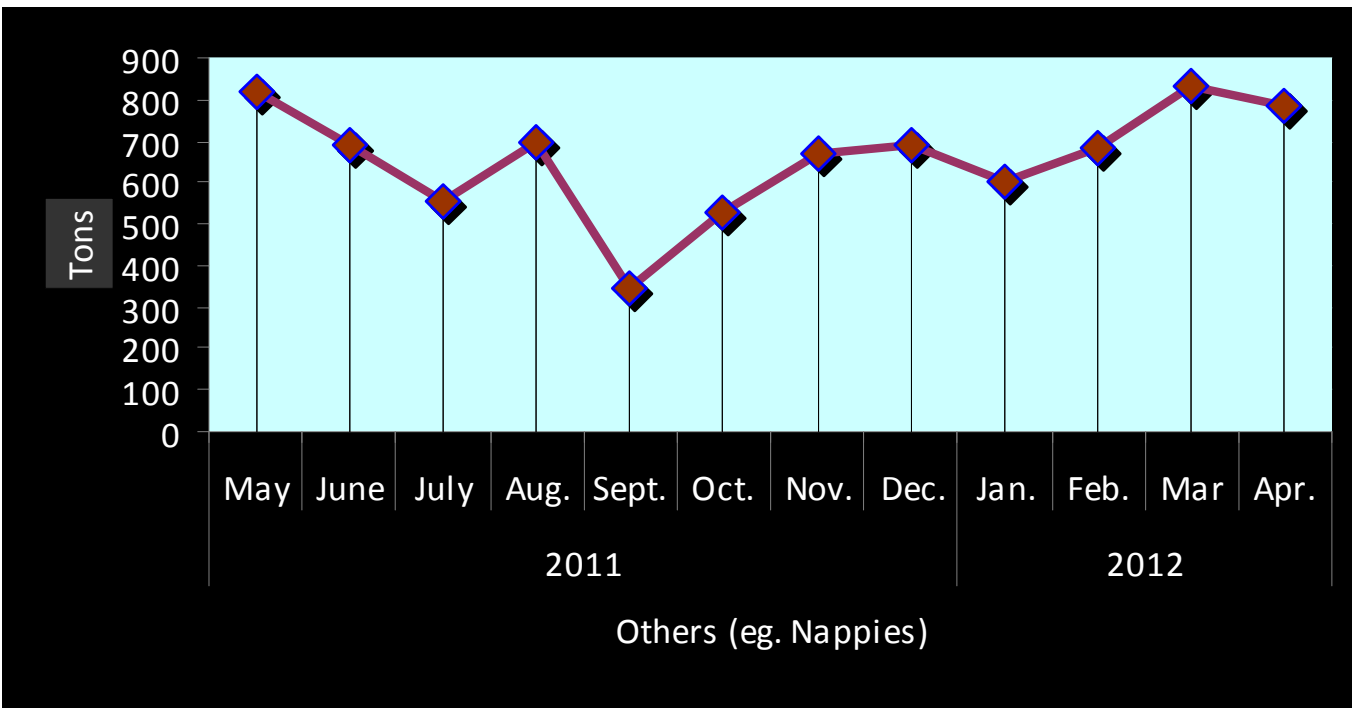

Figure 10. Monthly tonnages of total others (nappies, wood, tin) wastes generated in the households of Port Harcourt metropolis during the study period.

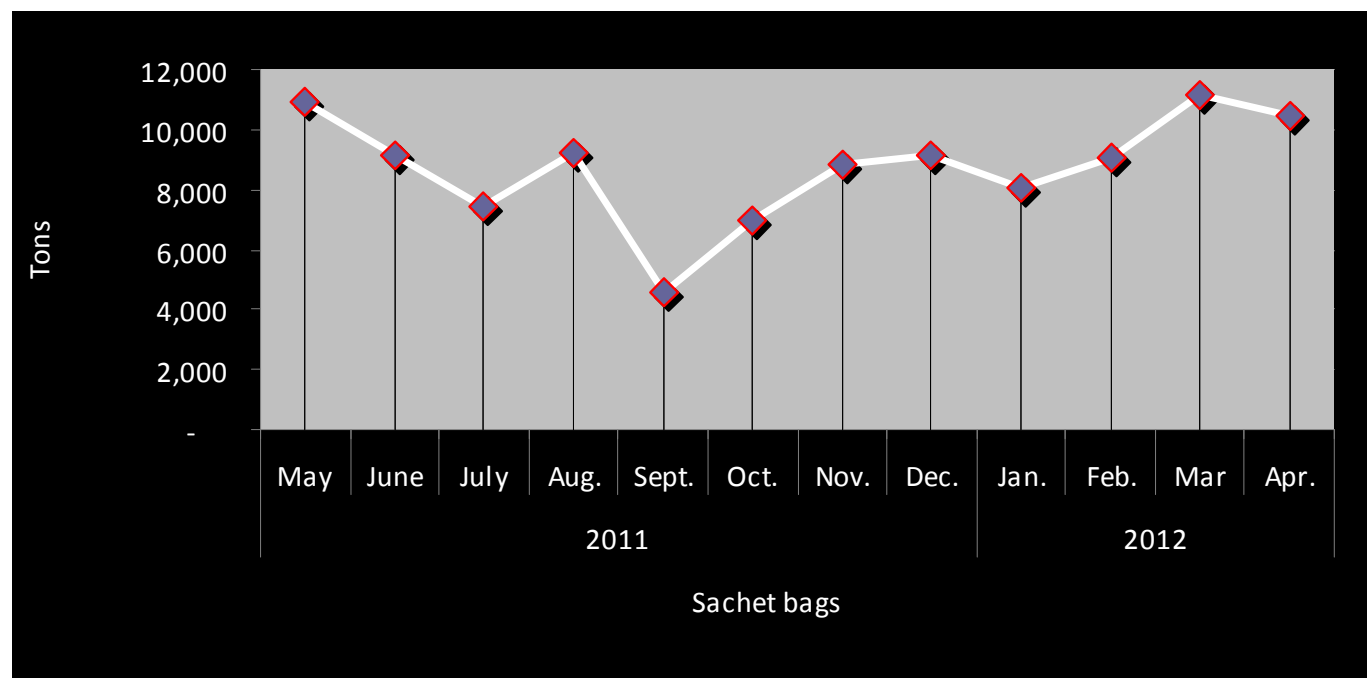

Figure 11. Monthly tonnages of total Sachet bag wastes generated in the households of Port Harcourt metropolis during the study period

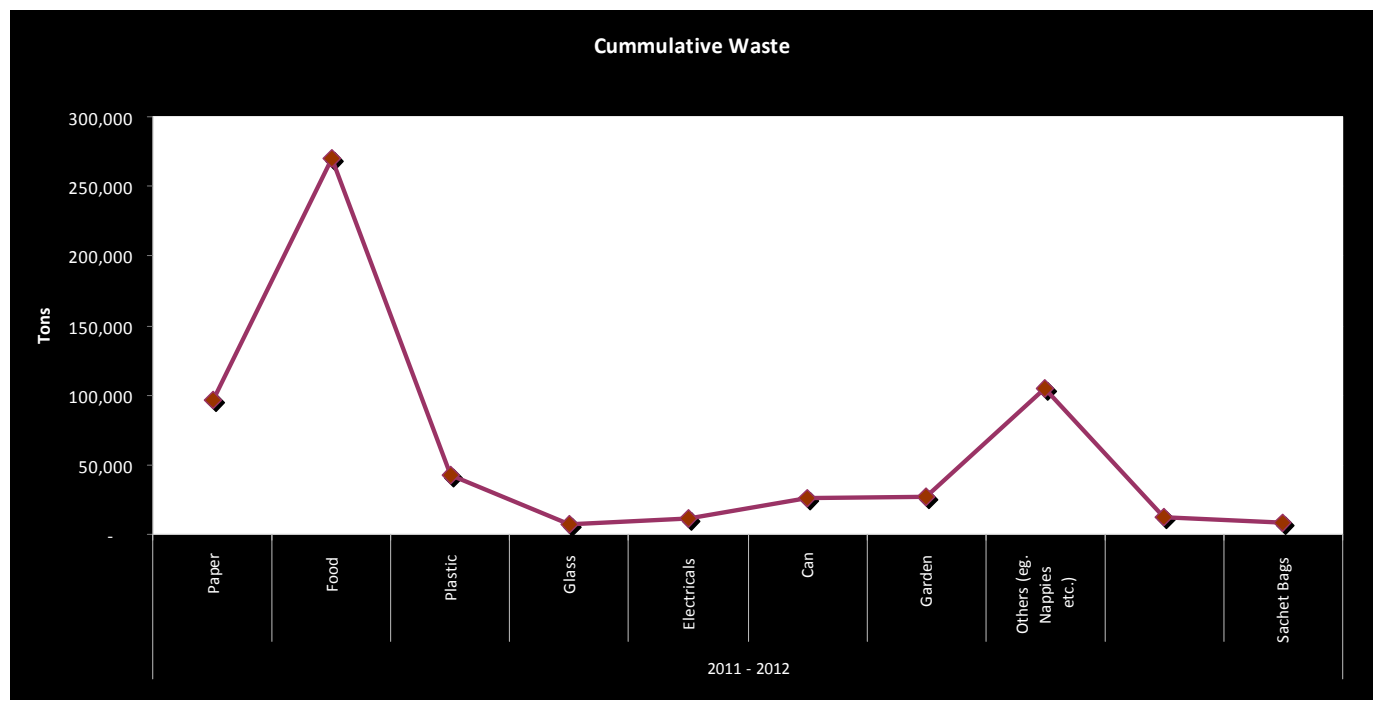

Figure 12. Cumulative wastes generated in the households of Port Harcourt metropolis during the study period. 
Table 4. Summary of Monthly Tonnages Recorded For May 2011 to May 2012.

\begin{tabular}{ll}
\hline MONTHS & TOTAL TONS \\
\hline May, 2011 & 63,069 TONS \\
June, 2011 & 52,846 TONS \\
July, 2011 & 42,900 TONS \\
August, 2011 & 53,196 TONS \\
September, 2011 & 26,405 TONS \\
October, 2011 & 40,410 TONS \\
November, 2011 & 46,503 TONS \\
December, 2011 & 52,419 TONS \\
January, 2012 & 51,058 TONS \\
February, 2012 & 52,978 TONS \\
March, 2012 & 51,736 TONS \\
April, 2012 & 55,328 TONS \\
May, 2012 & 58,218 TONS \\
\hline
\end{tabular}

Source: Firimabo Nig. Ltd and Rivlink Nig. Ltd Port Harcourt, Rivers State

\section{Discussion}

Generally, waste of all forms are primarily the creation of normal human living, it is to be expected that the more people living in a particular space, the more acute will be the problem of waste. Population therefore constitutes a vital component of urban solid waste management and disposal [4]. The 1991 base population census figure for Rivers State Nigeria was 4,309,557 with Port Harcourt metropolis (Port Harcourt LGA and Obio Akpor LGA) standing at 703,416 (1991 Population Census of the Federal Republic of Nigeria, Rivers Statistical table). The population of Port Harcourt Metropolis according to official gazette of the 2006 census final result is 1,000,908 [25]. The nationally adopted annual growth for rural areas is $2.5 \%$ while that for urban area is $3.0 \%$ [26]. A joint study by both the Rivers State Ministry of Environment and Nigerian Agip Oil company Limited for Port Harcourt estimated 342,352 metric tons of municipal solid waste generated in Port Harcourt metropolis in the year 2001 compared to 273,095 metric tons in 2000 representing $25.4 \%$ increase in annual waste generating rate in the city [27]. The report by Rivers State Environmental Sanitation Authority showed that in 2006, 423,500 metric tons of waste was generated in Port Harcourt metropolis with the composition as follows; Organic 41\%, Paper/Plastic 35\%, Metal/Glass $15 \%$, Construction $4 \%$, Sludge $3 \%$, and Hazardous $2 \%$. The data from this research showed that household waste generated in Port Harcourt metropolis from May, 2011 to April 2012 stood at 647,066 metric tons with $5 \%$ error.

The percentage compositions of waste are as follows; Food $44.5 \%$, Sachet bags $17.3 \%$, Paper $15.9 \%$, Plastic $7.1 \%$, Garden waste $4.4 \%$, Textile $2.2 \%$, Electrical $1.8 \%$, Glass $1.2 \%$, and others (nappies, wood, tin) $1.3 \%$. The inefficient management of these waste stream contributes to flooding, air pollution and public health impacts such as respiratory ailments, diarrhea and dengue fever [6]. A good waste management system starts from the generation point or source by bagging them in a bin liner and placed in a sanitary refuse bin and wait for the service provider disposal van or truck that comes at a specified time or day in a week.

\section{Conclusion and Recommendation}

The analysis of the household waste collected shows an increase in the quantity generated in successive years studied; 273,095 metric tonnes in 2000,342,353 metric tonnes in 2001,423,500 in 2006 and 647,066 metric tonnes in 2011. The study revealed that there was inadequate infrastructure and funding to manage the growing quantities of household waste. All these are potential and virtual obstacles to sustainable waste management in Port Harcourt, Rivers state Nigeria. Population therefore constitutes a vital component of urban solid waste management and disposal and Port Harcourt currently has an estimated population of 3,02,000 [28]. The results of this research will fully harness and utilize alternative options available in managing waste, thus reducing reliance on dumpsites as well as minimize emission of green house gases while managing waste in an environmentally sound, socially responsible and financially sustainable manner. The results of this study will be a data bank for further research as the team is set to conduct similar studies in 2021 i.e another ten (10) years after.

The problem of waste management in Port Harcourt has four dimensions; the People, Government, Service Provider and Finance. The people should be taught on how to segregate waste from the source of generation to the point of disposal. Waste should not be disposed into the public drain and road median as it is currently practiced in Port Harcourt; for this is one of the bane of sustainable development in the State as it tends to drive away tourist and potential investors from the City.

Government should also as a matter of urgency public recycling plants and modern incinerators in Port Harcourt inorder to reduce the volume of waste in the State and it will also create employment for the youth. This is because absence of recycling plants in the State has hindered the smooth operation of waste disposal system. Also Government should try to complete the Scrap to Wealth Project and Waste to Wealth Project under construction as to free Port Harcourt from indiscriminate disposal of waste.

The Service Providers as a matter of urgency should take a holistic approach to collaborate with Government and buy up some properties along the roads and demolish same for use as collection-centers for waste. This; if properly handled will solve the problem of indiscriminate disposal of householdwaste and littering on the centre of our high ways and roads.

\section{References}

[1] B. Wood, "Taking waste to new levels," The Journal for Waste and Resource Management Professionals, vol. 5, pp. 40-45, 2009. 
[2] T. E Amalu, and A. O. Ajake, "Appraisal of solid waste management practices in Enugu City," Nigerian. Journal of Environmental and Earth Science,. vol. 4, issue 1, pp. 97 - 98, 2014.

[3] K. A Ayuba, L. A. Manaf, A. H Sabrina and S. W. Azmin, "Current status of municipal solid waste management practice in FCT Abuja," Research Journal of Environmental and Earth Sciences, Vol. 5 issue 6, pp. $296-304,2013$.

[4] M. J. Ayotamuno and A. E. Gobo," Municipal solid waste management in Port -Harcourt, Nigeria; obstacles and prospect," Management of E-nvironmental Quality. An International Journal, vol. 15, issue 4, pp. -358 - 389, 2004.

[5] J. E. Umunnakwe, I. K. E. Ekweozor, and B. A. Umunnakwe. "Impact of lifestyle scenarios on household wastes in Port Harcourt", Management of Environmental Quality: An International Journal,. Vol. 30 Issue: 4, pp. 864 - 889, 2019. https://doi.org/10.1108/MEQ-04-2018-0079.

[6] D. Hoornweg, and P. Bhaza-Tata, "A global review of solid waste management" Urban Development Series Knowledge Papers, vol. 15, pp. 30-35, 2012.

[7] World Bank report on solid waste management. Urban development and local government unit, Washington, USA. www.worldbank.org/urban 2012.

[8] E. T. Iriruaga. "Solid waste management in Nigeria," D-Waste waste management for all, pp. 1-6, 2012.

[9] LAWMA, Lagos State Waste Management Authority. Lagos state Government, Nigeria, 2012.

[10] BUKCU, Bayero University Consultancy Unit. Bayero University Kano, -Nigeria 2012.

[11] W. A. Ogosu, "Urbanization and the challenges of enhancing clean and healthy environment", Paper presented at Nigerian Environmental Society Technical Session at Federal Secretarial Complex, Port Harcourt Rivers State, Nigeria, February 2011.

[12] E. I Elenwo, "Solid waste management practices in Port Harcourt -metropolis: Problems and prospects," Journal of Geographic thought and -Environmental Studies, vol. 13, issue 1, pp. 60-81, 2015.

[13] C. F. Ikebude. "Feasibility study on solid waste management in Port Harcourt metropolis: Causes, effects and possible solutions," Nigerian Journal of Technology, Vol. 36, issue 1, pp. 276-281, 2017.

[14] R. Irina,"Oil boom in Nigeria and its consequencies for the country's economic development Munich," GRIN Verlas, pp. 15-34, 2007.
[15] O. H. Uchenna,"Household waste disposal laws in the Federal Republic of Nigeria. Georgia state University”, Scholar works, 2016.

[16] M. O Agwu, "Issues and Challenges of solid waste management practices in Port Harcourt city, Nigeria- a behavoural perspective," Ambio. J. Soc Mgmt. Sci,. vol 3, issue 2, pp. 83-92, 2012.

[17] D. N. Ogbonna. "Use of burrow pits a relatively inexpensive practical mode of waste disposal in Nigeria" Journal of Nigerian Environmental Society. Vol. 2 issue 2, pp. 210-215, 2002.

[18] M. K. C Sridher, A. O Jegede, and Z. Uwadiegwu. "Waste management policy and implementation". National Journal of Advanced Research. Vol. 3 issue 3, pp. 23-35, 2017.

[19] I. Owate, "Classification and rate of generation of solid wastes in Port Harcourt". Paper Presented at a Workshop on Solid Waste Management Problems and Solution in the Niger Delta at Civic Centre, Port Harcourt, Rivers State. 2002.

[20] Rivers State Refuse Collection and Disposal Edict. Port Harcourt: Government Printing Press, 1991.

[21] Technical Committee on Urban Solid Waste Management. Reports on Assessment /Information, Data Gathering and Analysis on Urban Solid Waste Management for Port Harcourt and its Environs; for Government of Rivers State and Nigeria Agip Oil Company, 2001.

[22] EPA. Environmental Protection Agency, Decision Makers, Guide on Solid Waste Management. Washington, DC: Washington Office of Solid Waste Programmes, 1976.

[23] C. V. Ramastry. "Estimation of solid wastes in Edo State Nigeria" Paper presented at the National Policy Seminar on Environmental Issues and Management in Nigerian Development, University of Benin, Nigeria. 1985.

[24] J. F. Olorunfemi and C. O. Odita. "Land use and solid waste generation in Ilorin, Kwara State Nigeria", The Environmentalist, Vol. 18 issue 2, pp. 55-57, 1988.

[25] Federal Republic of Nigeria Official Gazette. Legal Notice on Publication of 2006 census final results. Federal Government Print, Abuja, Nigeria, 2009a.

[26] Federal Republic of Nigeria Official Gazette. Report on the Census 2006 final results. Federal Government Print, Abuja, Nigeria, 2009b.

[27] D. N. Ogbonna, I. K. E. Ekweozor, and F. U. Igwe, "Waste management: A tool for environmental protection in Nigeria", Ambio, vol. 31, pp. 55-70, 2002.

[28] United Nations world population prospect. Metro Area Population 1950-2020, Port Harcourt, Nigeria, 2020. 